\title{
Effect of Lactobacilli Symbiotic on Rumen, Blood, Urinary Parameters and Milk Production of Jersey Cattle During Late Pregnancy and Early Lactation
}

ISSN: 2640-9208

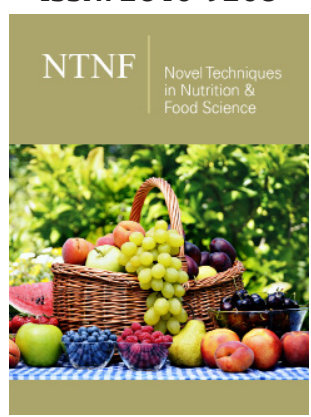

*Corresponding author: Galina MA, Facultad de EstudiosSuperioresCuautitlan, México.

Submission: 泟 October 15, 2020

Published: 㭗 November 03, 2020

Volume 5 - Issue 3

How to cite this article: Galina MA*, Rosa Isabel Higuera Piedrahita, Pineda J, Puga DC, Hummel JD, Ortíz RM, Haenlein GFW. Effect of Lactobacilli Symbiotic on Rumen, Blood, Urinary Parameters and Milk Production of Jersey Cattle During Late Pregnancy and Early Lactation. Nov Tech Nutri Food Sci. 5(3). NTNF. 000611. 2020. DOI: 10.31031/NTNF.2020.05.000611

Copyright@ Galina MA. This article is distributed under the terms of the Creative Commons Attribution 4.0 International License, which permits unrestricted use and redistribution provided that the original author and source are credited.

\author{
Galina MA ${ }^{1 *}$, Rosa Isabel Higuera Piedrahita ${ }^{1}$, Pineda ${ }^{2}$, Puga DC ${ }^{3}$, Hummel JD ${ }^{2}$, \\ Ortíz RM ${ }^{1}$ and Haenlein GFW ${ }^{4}$ \\ ${ }^{1}$ Facultad de EstudiosSuperioresCuautitlan, México \\ ${ }^{2}$ Department of Veterinary Medicine and Zootechnics, México \\ ${ }^{3}$ Department ofNutrición, México \\ ${ }^{4}$ Departament of Animal and Food Sciences, USA
}

\begin{abstract}
An experiment was conducted to measure the effects of feeding Lactobacilli (LAB) with a slow intake urea supplement (SIUS) blended into a probiotic/prebiotic mixture, fed at pre partum and early postpartum, using 84 Jersey cows. Two integrated diets (ID), pre and postpartum, were fed to two groups of 42 cows: first, pre partum starting $21 \mathrm{~d}$ before calving as follows: 1) ID without supplement 2) ID with LAB/SIUS; Second, post calving cows (20 animals each) were fed a lactation diet (LD) T1 with LAB/ SIUS pre and postpartum, T2 LAB/SIUS only prepartum, T3 LAB/SIUS only postpartum and T4 without LAB/SIUS supplementation. LAB probiotic supplementation contained approximately $4 \times 107 \mathrm{cfu}$ of lactic acid bacteria composed of $4 \times 106 \mathrm{cfu}$ of Lactobacillum plantarum; 10x106cfu of Lactobacilumdelbrueckii; 8x106cfu L. helveticus; 10x106cfu Lactococcus lactis; 10x106cfu Leuconostocmesenteroides; and 5x104cfu of Bifidus spp. mixed into a liquid $250 \mathrm{~g}$ supplement/cow per d in both pre partum and post-partum periods. SIUS composition was: $17 \%$ corn, $17 \%$ molasses, $16 \%$ poultry litter, $14 \%$ rice polishing, $8 \%$ cottonseed meal, $5 \%$ lard, $4 \%$ fish meal, $4 \%$ salt, $4 \%$ urea, $3.2 \%$ calcium carbonate, $3 \%$ orthophosphate, $2.2 \%$ ammonium sulfate, $1.6 \%$ cement kiln dust and $1 \%$ mineral salt. DMI, milk yield, and milk protein content were higher for cows receiving the LAB/SIUS probiotics compared with the LAB/SIUS diet $(\mathrm{P}<0.05)$. Blood glucose, insulin levels, plasma nonesterified fatty acids (NEFA) and BHBA were higher suggesting that LAB/SIUS supplementation increased DMI and milk production due to more glucose available when administrated continually, with an intermediate metabolic response when LAB/SIUS was given only pre or postpartum. Blood metabolite information suggested that the response was associated with more glucose being made available and fewer fatty acids being mobilized from lipid stores. Purines were significantly increased with the LAB/SIUS $\operatorname{diet}(\mathrm{P}<0.05)$. Adding a probiotic to the diet augmented DMI probably from a higher rumen cell wall utilization and development of bacterial protein from nonprotein nitrogen.
\end{abstract}

Keywords: Probiotics;Lactobacilli; Milk production;Cows;Supplementation;Blood parameters;Rumen parameters

\section{Introduction}

Probiotics and prebiotics have, recently, gained attention [1] for their role in controlling digestive infectious diseases and improving productive performance in cattle. Lactic acid bacteria are well known as probiotics and have been used as growth promoters, to prevent intestinal infections by pathogenic bacteria, decrease stress, and stimulate immune response [2]. A beneficial bacterium, such as Bifido-bacteria, Lactobacilli and some species of Enteroccocci, provide nutrients for the animal intestinal cells, promote absorption of nutrients, create a healthy intestinal environment, and promote a vigorous immune system [3]. Prebiotics have been defined as selective non-digestible carbohydrate food sources that promote the proliferation of Bifidobacteria and Lactobacilli [4]. It has been reported that symbiotics (combination of pre and probiotics), mixed into feed improve milk production in Holstein dairy cows, inhibit Salmonella contamination, and prevent diarrhea while increasing weight gain in calves [5]. 
Nutritionists now consider that the transition period, which is the time between the last 2-3 weeks of gestation (close-up dry period) and the first 2 weeks of lactation (early fresh period), are the key phases in the lactation cycle. During this period, cows go through a high demand of nutrients, a phase associated with important physiological, metabolic and dietary changes. This vulnerable period, which can be extended for a further 3 weeks until the peak of lactation, represents a turning point in the productive cycle of cows [6]. To improve milk yield and quality [7] offered LAB supplementation with a direct-fed combination of Lactobacillum plantarum and Enterococcus faecium beginning $21 \mathrm{~d}$ prepartum through d 70 of lactation, increasing DMI, milk production, and milk protein percentage through the first $21 \mathrm{~d}$ of lactation. This bacteria mixture was supplemented daily into the rumen to increased ruminal $\mathrm{pH}$ within the diurnal cycle. The results showed diminished lactate formation to sequester more lactate at specific times, when lactic acid concentrations undulated as a result of the diurnal feeding behavior. LAB supplementation increased DMI and milk production in early lactation. Blood metabolite information suggested this response was associated with more glucose being made available and fewer fatty acids being mobilized from lipid stores [7]. The rational for this response was that the supplemented direct-fed-microbials (DFM) were providing a constant level of lactic acid to the rumen microbiota. The tonic production of lactate might allow the fastidious lactate-utilizing microbes to sustain a metabolic active population [7].

Bacteria of the genus Lactobacillus (LAB) have been proven to be beneficial microorganisms of particular interest because of their long successful history in human health [8]. Lactobacilli were among the first organisms used by man for processing foodstuffs [9] and for preserving food by inhibiting invasion by some pathogen microorganism [10]. Supplementation with LAB probiotics as beneficial microorganisms could be an important alternative for feeding dairy ruminants [11]. Previously, the use, of LAB probiotics in ruminants demonstrated enhanced performance, used alone or with slow consumption nitrogenous supplements to improve rumen fermentation $[11,12]$. LAB probiotics resulted in accelerated growth when feeding different diets. Stimulation of lactic acid fermentation showed nutraceutical functions due to bacteriocin production that destroyed pathogenic bacteria, or methane-forming bacteria, coupled with improving the quality of the supplement for their fibrolytic capacity. Adding prebiotic ingredients, which cannot be digested by ruminants in the alimentary tract, such as oligosaccharides or dextran, stimulate growth of lactic acid bacteria $[5,13]$. The objective of this study was to evaluate the effect of LAB/ SIUS supplementation (probiotic/prebiotic) during the pre-and post-partum period on rumen, blood, urinary parameters and milk production performance of dairy cattle.

\section{Material and Methods}

Eighty-four multiparous Jersey cows, weighing $540 \mathrm{~kg}( \pm 22 \mathrm{~kg})$ were selected and placed into two treatments and used in the present study from 3 weeks pre partum throughout 10 weeks postpartum. Cows were blocked by previous lactation milk yield $(24 \mathrm{~kg} / \mathrm{d})$. The treatment groups consisted of two pre partum integrated diets (with or without LAB/ SIUS) offered to two groups of 42 cows each, randomly distributed (Table 1). After calving, 80 cows were subdivided into four groups one fed LAB/SIUS before and after calving (T1), a second fed LAB/SIUS only during lactation (T2), a third group fed LAB/SIUS before calving but not during lactation (T3) and a fourth group of cows that did not receive LAB/ SIUS either before or after calving (T4). Cows post-partum averaged $22 \mathrm{~kg}( \pm 2.7) \mathrm{milk} / \mathrm{d}$.

Of The number of animals (76) that completed the trial, 4 animals were removed due to calving complications, mastitis or laminitis. The number of animals that completed the trial for each group was 18, 19, 19, 20 for T4; T3; T2; T1 respectively. No clinical ketosis or other metabolic diseases were diagnosed. The ingredient and nutritional composition of the two prepartum diets are in Table 1 . SIUS composition was: $17 \%$ ground corn, $17 \%$ molasses, $16 \%$ poultry litter, $14 \%$ rice polishing, $8 \%$ cottonseed meal, $5 \%$ lard, $4 \%$ fish meal, $4 \%$ salt, $4 \%$ urea, $3.2 \%$ calcium carbonate, $3 \%$ orthophosphate, $2.2 \%$ ammonium sulfate, $1.6 \%$ cement kiln dust and $1 \%$ mineral salt. The LAB probiotic supplementation contained approximately $4 \times 107 \mathrm{cfu}$ of lactic acid bacteria composed of $4 \times 106 \mathrm{cfu}$ Lactobacillum plantarum; 10x106cfu Lactobacilumi delbrueckii; 8x106 cfu L. helveticus; 10x106cfu Lactococcus lactis; 10x106cfu Leuconostoc mesenteroides, and 5x104 cfu Bifidus spp. blended into a liquid supplement mixture (prebiotic) of $35 \%$ molasses, and $65 \%$ cheese whey, $250 \mathrm{~g}$ of which were offered to each per cow per day, in both pre partum and post-partum periods. The two lactating diets are in Table 1.

Table 1: Pre partum diets offered $21 \mathrm{~d}$ before calving and throughout parturition.

\begin{tabular}{|c|c|c|c|c|}
\hline & $\begin{array}{c}\text { Pre-Partum } \\
\text { Diet }\end{array}$ & $\begin{array}{l}\text { Pre-Partum Diet } \\
\text { LAB/SIUS }\end{array}$ & $\begin{array}{c}\text { Post-Partum } \\
\text { Diet }\end{array}$ & $\begin{array}{c}\text { Post-Partum Diet } \\
\text { LAB/SIUS }\end{array}$ \\
\hline Ingredient & \% DM basis & \% DM basis & \% DM basis & $\%$ DM basis \\
\hline LAB/SIUS Probiotic & & 10.4 & & 9.04 \\
\hline Cotton seed & $10.40^{*}$ & & $9.04^{*}$ & \\
\hline Barley straw & 5.44 & 5.44 & 4.98 & 4.98 \\
\hline Ground corn & 35.75 & 35.75 & 24.35 & 24.35 \\
\hline Soybean oil meal & 11.95 & 11.95 & 8.09 & 8.09 \\
\hline Alfalfa hay & 5.46 & 5.46 & 5.94 & 5.94 \\
\hline Corn silage & 21.25 & 21.25 & 32.48 & 32.48 \\
\hline
\end{tabular}




\begin{tabular}{|c|c|c|c|c|}
\hline Ground barley meal & 8.95 & 8.95 & 13.88 & 13.88 \\
\hline Minerals & 0.8 & 0.8 & 24 & 1.24 \\
\hline CP \% & 19.9 & 21.1 & 43.4 & 4.2 \\
\hline UIP \% of CP & 42.1 & 44.1 & 1.89 & 1.94 \\
\hline DIP \% of CP & 69 & 72 & 30.2 & 31.5 \\
\hline NDF \% & 33.4 & 31.4 & 17.4 & 16.2 \\
\hline ADF \% & 16.8 & 16.1 & 40.5 & 41.5 \\
\hline NFC \% & 40.5 & 42 & 0.4 & 0.5 \\
\hline Mg \% & 0.38 & 0.4 & 4.3 & 4.4 \\
\hline Fat \% & 4.3 & 4.4 & 1.5 & 1.7 \\
\hline Ca \% & 1.28 & 1.21 & 0.5 & 0.6 \\
\hline P \% & 0.52 & 0.57 & & \\
\hline
\end{tabular}

LAB: Lactic Acid Bacteria Probiotic; SIUS: Slow Intake Urea Supplement

${ }^{*}$ LAB/SIUS substituted cotton seed in the diet.

Two ruminally cannulated cows $(560 \pm 27 \mathrm{~kg}$ BW) were placed into each experimental prepartum diet. Thereafter cannulated cows were changed to each postpartum treatment under a Latin Square design, allowing $7 \mathrm{~d}$ of adaptation before sample collection on each diet. Ruminal fluid was collected at 0 (before feeding) and 2, 4, 6, 8, 10 and $12 \mathrm{~h}$ (after feeding) to measure $\mathrm{pH}$ and NH3 with an iron selective electrode probe (Orion Research 1997). VFA were determined by gas chromatography with the method described before [14]. About $100 \mathrm{ml}$ of rumen fluid was passed through two layers of gauze and kept in a $\mathrm{CO}_{2}$ pre-gassed thermos flask. In the laboratory, the filtered rumen fluid was immediately transferred into smaller bottles while gassing with $\mathrm{CO}_{2}$. The bottles were stored in an incubator at $39^{\circ} \mathrm{C}$ before dilution and inoculation. Rumen fluid was diluted (106 to 108 ) and $0.5 \mathrm{ml}$ of each of the three dilutions was inoculated and incubated anaerobically before colonies were counted, following the technique described by Hungate [15]. Samples of the probiotic bacteria were identified in anaerobic chambers as detailed before [11]. Rumen fluid samples were also obtained via a stomach tube in pregnant cows and early lactation 3 h post feeding on $\mathrm{d} 14,10,5$, and d 1 pre partum. After parturition, ruminal samples via stomach tube were obtained every $7 \mathrm{~d}$. Both ruminal fluids directly from cannulated animals and via the stomach tube on experimental animals were examined simultaneously.

Digestibility was determined with the fistulated animals through total fecal collection from net feed intake (difference between offered and refused feed, with a $10 \%$ restriction to ensure complete intake for dry matter (DMI). Organic matter (OM) and crude protein (CP) were determined, according to AOAC [16]. Preand post-partum diets, blended with the supplement, were offered as a total mixture (TM) twice a day to assure at least $10 \%$ refusal. Weights were recorded before the morning feeding and discarded. Daily DMI in 5 selected cows in each treatment, was measured for the entire trial period. In addition, daily milk production and weekly composition was measured during the postpartum period. All forages and diets were sampled weekly, stored frozen and analyzed for CP [16], NDF [17] (Van Soest et al., 1992), Ca, P, and Mg [16]. Total daily urine production was collected from 5 randomly selected animals every week from 21d before and throughout parturition, continuing from calving to the end of the study. Microbial nitrogen supply was calculated from purine derivative excretion (PDe) in urine according with the methodology of [18], following the equation:

$$
Y=0.85 X+\left(0.147 W^{0.75}\right)
$$

Where $\mathrm{Y}$ and $\mathrm{X}$ represent: the excretion of PDe in urine (Ymmol/d) and absorption of microbial purines (Xmmol/d), $W 0.75=$ the metabolic body weight $(\mathrm{kg})$ of the cow. The slope 0.85 represents the recovery of absorbed purines as PDe in urine. The component within parentheses represents the net endogenous contribution of PDe to total excretion after correction for the utilization of microbial purines by the animals [19]. Calculations of intestinal flow of microbial nitrogen were according to the following equation:

$$
\text { Microbial } N(g N / d)=\frac{x(m m o l) \times 70}{0.116 \times 0.83 \times 1000}=0.727 X
$$

Where, digestibility of microbial purines is assumed to be 0.83 . This is taken as the mean digestibility value for microbial nucleic acids. The nitrogen content of purines is $70 \mathrm{mg} / \mathrm{mmol}$ and the ratio of purine $\mathrm{N}$ : total $\mathrm{N}$ in mixed rumen microbes is taken as 11.6:100 [18,19]. Blood samples were taken weekly 21d before and throughout parturition, continuing daily from parturition to the end of the study. Blood samples were taken before the morning feeding, which would correspond to the time of the highest NEFA ((Plasma non-esterified fatty acids) and BHBA (Blood $\beta$ hydroxybutyrate). Rumen fluid samples were obtained on fistulated animals $3 \mathrm{~h}$ post feeding on d 14, 10, 5, and d 1 pre partum. NEFA and glucose concentrations were determined by calorimetric assay with commercial kits (WAKO Chemicals, Dallas TX and kit 510 Sigma Chemical CO., St. Louis, Mo, respectively). Plasma BHBA 
was determined by the method of [20]. Insulin was determined by radioimmunoassay (Coat-a-count Insulin, Diagnostic Products Corporation, Fort Collins, Col) following the proposal by Nocek et al. [7]. Results were evaluated by split-plot-in-time for repeated measures procedure of SAS: dependent variable $=\mu$ +treatment + period + cow (treatment) + treatment*period $+\xi$, where $\mu$ is the overall mean of the population and $\xi$ is the random error. When treatment was significant $(\mathrm{P}<0.05)$, Tukey-Kramer test was used to identify treatment effects within the period as described by Nocek et al. [7]. Fistulated cows were evaluated in pre partum by ANOVA. After parturition fistulated animals were analyzed under a 4 Latin square design.

\section{Result}

Dry matter intake response was reported for $21 \mathrm{~d}$ throughout pre partum until calving (Table 2). There was a difference between
LAB/SIUS on DMI 21 throughout $8 \mathrm{~d}$ pre partum $(\mathrm{P}<0.05)$. DMI was reduced in the last $7 \mathrm{~d}$ versus the previous $14 \mathrm{~d}$ prior to expected calving, but not significantly. Regardless of treatment, both NEFA and BHBA levels were higher $(\mathrm{P}<0.05)$ for the last $7 \mathrm{~d}$ compared to the previous $14 \mathrm{~d}$ before expected calving date (Table 2). Treatment with LAB/SIUS had no effect on either blood parameter pre partum. Results showed LAB/SIUS supplementation influenced ruminal $\mathrm{pH}$, from 5 through d 1 pre partum, with cows supplemented with LAB/SIUS having a higher $\mathrm{pH}$ value than in non-supplemented cows, preventing lactic acidosis and permitting better ruminal environment for the fibrolytic effect of lactic acid bacteria. Cows supplemented with LAB/SIUS showed less of a decline inrumen $\mathrm{pH}$ when compared to an average $\mathrm{d} 14$ and $\mathrm{d} 10$ pre partum to $\mathrm{d} 1$ pre partum (Table 3). Probiotic effect (LAB) did diminish ruminal $\mathrm{pH}$ significantly (Table 3). Prebiotic effect of SIUS allowed persistence of LAB in the rumen.

Table 2: Dry matter intake, plasma concentration of BHBA and NEFA of cows, prepartum supplemented with probiotics.

\begin{tabular}{|c|c|c|c|c|c|}
\hline \multicolumn{5}{|c|}{ Days Pre partum } & \multicolumn{3}{c|}{ Last 7 d } \\
\hline & 21 pre partum until parturition & Control & LAB/SIUS & SEM \\
\hline & Control & LAB/SIUS & $7.2^{\mathrm{c}}$ & $8.9^{\mathrm{c}}$ & 0.8 \\
\hline DMI kg/d & $9.4^{\mathrm{b}}$ & $11.2^{\mathrm{a}}$ & $0.678^{\mathrm{a}}$ & $0.645^{\mathrm{a}}$ & 0.069 \\
\hline BHBA $\mu$ M/L & $0.490^{\mathrm{b}}$ & $0.502^{\mathrm{b}}$ & $411^{\mathrm{a}}$ & $421^{\mathrm{a}}$ & 33 \\
\hline $\mathrm{NEFA} \mu \mathrm{M} / \mathrm{L}$ & $303^{\mathrm{b}}$ & $323^{\mathrm{b}}$ & &
\end{tabular}

DMI: Dry Matter Intake; NEFA: Plasma Non-Esterified Fatty Acids; BHBA: Blood $\beta$ hydroxybutyrate $\mathrm{a}, \mathrm{bEffect}$ of period values in the same row with different superscripts are different $(\mathrm{P}<0.05)$.

Table 3: Ruminal pH, VFA and NH3 at different pre partum times for cows supplemented with or without SIUS and LAB.

\begin{tabular}{|c|c|c|c|c|c|}
\hline \multicolumn{6}{|c|}{ Days Pre partum } \\
\hline & 14 to $10 \mathrm{~d}$ & $5,4,3 \mathrm{~d}$ & $2 \mathrm{~d}$ & $1 \mathrm{~d}$ & SEM \\
\hline \multicolumn{6}{|c|}{ Ruminal pH } \\
\hline Control & $6.85^{\mathrm{a}}$ & $6.62^{\mathrm{a}}$ & $6.52^{\mathrm{b}}$ & $6.50^{\mathrm{b}}$ & 0.07 \\
\hline LAB/SIUS & $6.87^{\mathrm{a}}$ & $6.42^{\mathrm{a}}$ & $6.10^{\mathrm{b}}$ & $6.09^{c}$ & 0.03 \\
\hline \multicolumn{6}{|c|}{ Rumen VFA proportions (mM/l) Control } \\
\hline Acetate & $78.2^{\mathrm{a}}$ & $72.2^{\mathrm{a}}$ & $77.8^{\mathrm{a}}$ & $77.2^{\mathrm{a}}$ & 2.3 \\
\hline Propionate & $14.4^{\mathrm{b}}$ & $14.8^{\mathrm{a}}$ & $15.2^{\mathrm{a}}$ & $14.9^{\mathrm{ab}}$ & 1.2 \\
\hline Butyrate & $5.3^{\mathrm{b}}$ & $6.2^{\mathrm{a}}$ & $6.4^{\mathrm{a}}$ & $6.4^{\mathrm{a}}$ & 0.5 \\
\hline Total & $97.9^{\mathrm{b}}$ & $93.2^{\mathrm{c}}$ & $99.4^{\mathrm{a}}$ & $98.5^{\mathrm{ab}}$ & 1.2 \\
\hline \multicolumn{6}{|c|}{ Rumen VFA proportions (mM/l) LAB/SIUS } \\
\hline Acetate & $77.3^{\mathrm{a}}$ & $75.4^{\mathrm{a}}$ & $76.3^{\mathrm{a}}$ & $74.5^{\mathrm{a}}$ & 2.3 \\
\hline Propionate & $15.7^{\mathrm{a}}$ & $16.1^{\mathrm{a}}$ & $16.7^{\mathrm{a}}$ & $16.3^{\mathrm{a}}$ & 1.2 \\
\hline Butyrate & $5.1^{\mathrm{a}}$ & $5.9^{\mathrm{a}}$ & $5.9^{\mathrm{a}}$ & $6.1^{\mathrm{a}}$ & 0.5 \\
\hline Total & $98.1^{\mathrm{a}}$ & $97.4^{\mathrm{b}}$ & $98.9^{\mathrm{a}}$ & $96.9^{c}$ & 1.2 \\
\hline \multicolumn{6}{|c|}{ Rumen $\mathrm{NH}_{3}(\mathrm{mg} / 100 \mathrm{ml})$} \\
\hline Control & $14.9^{\mathrm{b}}$ & $14.4^{\mathrm{b}}$ & $14.7^{\mathrm{b}}$ & $14.9^{\mathrm{b}}$ & 1.7 \\
\hline LAB/ SIUS Probiotic & $15.9^{\mathrm{a}}$ & $17.4^{\mathrm{a}}$ & $17.7^{\mathrm{a}}$ & $17.9^{\mathrm{a}}$ & 2.2 \\
\hline
\end{tabular}

a,bMeans in the same row with different superscript are different for VFA $(\mathrm{P}<0.05)$

a,bMeans in the same column for ph and NH3 values with different superscript are different $(\mathrm{P}<0.05)$. 
Total VFA in both treatments did not show significant differences (Table 3). However, LAB/SIUS augmented rumen propionate that can lead to higher milk production. Ruminal NH3 was higher in the probiotic supplemented treatments; demonstrating a double effect, produced by the higher NPN from urea and ammonium sulphate and the probiotic effect of developing lactic acid bacteria in the treated animals (Table 3). Effects of LAB/SIUS supplementation postpartum are in Table 4. For DMI from d1 though d7, LAB/SIUS supplementation pre and postpartum resulted in an increase (T1). Cows fed LAB/SIUS post-partum only [T2] showed an intermediate response from other treatments (T1;T4). During week 2 and 3 postpartum, cows fed LAB/SIUS pre and post-partum (T1) had higher intakes than those fed no LAB/SIUS or fed LAB/SIUS only during the post-partum period. The effect $(\mathrm{P}<0.05)$ was demonstrated from d 22 through d 70. Milk production was higher from cows receiving $\mathrm{LAB} / \mathrm{SIUS}$ both pre and post-partum (T1), than for no LAB/SIUS; a slight increase in T3, but not different from the other treatments during week 1 post-partum (T2;T4). On d 8 through $\mathrm{d} 21$, cows consuming LAB/SIUS pre and post-partum (T1) and LAB/ SIUS pre partum (T3) produced more milk than cows receiving no LAB/SIUS (T4) or LAB/SIUS post-partum (T2) only but not different from those receiving LAB/SIUS post-partum only. This same general tendency $(\mathrm{P}<0.05)$ was demonstrated from week 3 through 10 post-partum. Although there were no significant effects of treatment on milk fat percentage, cows that received LAB/SIUS regardless of the stage tended to have numerically higher milk fat percentages than those that did not receive LAB/SIUS. During the first week post-partum, milk protein percentage was higher and similar among treatments ( $\mathrm{P}>0.05)$. From week 2 throughout 10 , cows in $\mathrm{T} 1$ and $\mathrm{T} 3$ produced milk with a higher protein percentage than those that did not receive LAB/SIUS (T4) or receiving LAB/ SIUS post-partum only (T2) from week 2 through 3 not different from the other treatments $(\mathrm{P}<0.05)$ (Table 4).

Table 4: Dry matter intake and production parameters for cows supplemented with or without LAB/SIUS as a probiotic post-partum.

\begin{tabular}{|c|c|c|c|c|c|}
\hline \multicolumn{6}{|c|}{ Lactation } \\
\hline Day & $\mathrm{T} 1$ & $\mathrm{~T} 2$ & $\mathrm{~T} 3$ & $\mathrm{~T} 4$ & SEM \\
\hline \multicolumn{6}{|c|}{ DMI kg/d } \\
\hline $1-7 \mathrm{~d}$ & $12.9^{\mathrm{a}}$ & $11.5^{\mathrm{b}}$ & $11.7^{\mathrm{b}}$ & $11.8^{\mathrm{b}}$ & 0.9 \\
\hline $8-21 \mathrm{~d}$ & $15.2^{\mathrm{a}}$ & $12.1^{\mathrm{b}}$ & $14.1^{\mathrm{b}}$ & $13.4^{\mathrm{b}}$ & 1.1 \\
\hline $22-70 \mathrm{~d}$ & $17.4^{\mathrm{a}}$ & $16.3^{\mathrm{b}}$ & $16.2^{\mathrm{b}}$ & $15.8^{\mathrm{b}}$ & 0.8 \\
\hline \multicolumn{6}{|c|}{ Milk, kg/d } \\
\hline $1-7 \mathrm{~d}$ & $17.3^{\mathrm{a}}$ & $16.1^{\mathrm{b}}$ & $16.5^{\mathrm{b}}$ & $14.7^{\mathrm{c}}$ & 0.5 \\
\hline $8-21 \mathrm{~d}$ & $23.2^{\mathrm{a}}$ & $21.1^{\mathrm{a}}$ & $21.7^{\mathrm{a}}$ & $19.4^{\mathrm{b}}$ & 0.7 \\
\hline $22-70 \mathrm{~d}$ & $27.3^{\mathrm{a}}$ & $25.0^{\mathrm{a}}$ & $26.2^{\mathrm{a}}$ & $21.2^{\mathrm{b}}$ & 0.8 \\
\hline \multicolumn{6}{|c|}{ Milk fat $\%$} \\
\hline $1-7 \mathrm{~d}$ & $6.68^{\mathrm{a}}$ & $6.45^{\mathrm{a}}$ & $6.55^{\mathrm{a}}$ & $6.35^{\mathrm{b}}$ & 0.04 \\
\hline $8-21 \mathrm{~d}$ & $6.35^{\mathrm{a}}$ & $6.27^{\mathrm{b}}$ & $6.45^{\mathrm{a}}$ & $6.24^{\mathrm{b}}$ & 0.02 \\
\hline $22-70 \mathrm{~d}$ & $6.20^{\mathrm{b}}$ & $6.14^{\mathrm{b}}$ & $6.35^{\mathrm{a}}$ & $6.12^{\mathrm{b}}$ & 0.05 \\
\hline \multicolumn{6}{|c|}{ Milk protein $\%$} \\
\hline $1-7 \mathrm{~d}$ & $4.01^{\mathrm{a}}$ & $3.91^{\mathrm{a}}$ & $4.10^{\mathrm{a}}$ & $3.94^{\mathrm{a}}$ & 0.01 \\
\hline $8-21 \mathrm{~d}$ & $3.86^{\mathrm{a}}$ & $3.33^{\mathrm{b}}$ & $3.97^{\mathrm{a}}$ & $3.24^{\mathrm{b}}$ & 0.05 \\
\hline $22-70 \mathrm{~d}$ & $3.30^{\mathrm{a}}$ & $3.17^{\mathrm{b}}$ & $3.45^{\mathrm{a}}$ & $3.05^{\mathrm{b}}$ & 0.1 \\
\hline
\end{tabular}

abMeans in the same row with different superscripts are different $(P<0.05)$

T1 $=$ LAB/SIUS pre-and post-partum

T2=LAB/SIUS post-partum

T3=LAB/SIUS pre partum

\section{T4=No LAB/SIUS}

During the first 3 weeks post-partum, there was a treatment effect on blood BHBA and NEFA. After $22 \mathrm{~d}$ post-partum feeding LAB/SIUS pre and post-partum $(\mathrm{T} 1)$ reduced $(\mathrm{P}<0.05)$ BHBA and NEFA compared to no supplementation (T4) or only postpartum (T2), (Table 5). Supplementation with LAB/SIUS (T1; T3) had a significant influence on blood glucose, insulin, BHBA, and NEFA compared with T2; T4 (Table 5) $(\mathrm{P}<0.05)$. LAB/SIUS supplementation pre and post-partum (T1; T2; T3) increased $(\mathrm{P}<0.05)$ glucose and insulin concentration compared with no LAB/SIUS (T4). However, values were numerically higher for those fed LAB/SIUS post-partum (T2) compared with those that received no LAB/SIUS (T4) or those receiving LAB/SIUS only during the pre- 
partum period (T3). During the first 3 wks post-partum, there was no treatment effect on blood BHBA or NEFA. After $22 \mathrm{~d}$ post-partum feeding, LAB/SIUS pre and post-partum reduced $(\mathrm{P}<0.05)$ BHBA and NEFA compared with no supplementation or only pre partum T3 (Table 5).

Table 5: Blood parameters for cows supplemented with or without LAB/SIUS as a probiotic both pre- and post-partum.

\begin{tabular}{|c|c|c|c|c|c|c|c|}
\hline \multicolumn{8}{|c|}{ Treatment } \\
\hline & \multicolumn{2}{|c|}{ Pre partum } & \multicolumn{5}{|c|}{ Post-partum } \\
\hline Day & Control & LAB/SIUS & $\mathrm{T} 1$ & $\mathrm{~T} 2$ & T3 & $\mathrm{T} 4$ & SEM \\
\hline \multicolumn{8}{|c|}{ Glucose mg/dl } \\
\hline $1-7 \mathrm{~d}$ & $49.8^{\mathrm{b}}$ & $57.6^{\mathrm{a}}$ & $58.9^{\mathrm{a}}$ & $54.5^{\mathrm{b}}$ & $57.2^{\mathrm{a}}$ & $51.5^{\mathrm{b}}$ & 3.9 \\
\hline $8-21 \mathrm{~d}$ & $50.6^{\mathrm{b}}$ & $56.4^{\mathrm{a}}$ & $55.2^{\mathrm{a}}$ & $62.3^{\mathrm{b}}$ & $54.3^{\mathrm{a}}$ & $50.1^{\mathrm{b}}$ & 2.1 \\
\hline $22-70 \mathrm{~d}$ & $51.3^{\mathrm{b}}$ & $59.2^{\mathrm{a}}$ & $67.4^{\mathrm{a}}$ & $65.4^{\mathrm{a}}$ & $60.4^{\mathrm{b}}$ & $51.8^{\mathrm{b}}$ & 2.8 \\
\hline \multicolumn{8}{|c|}{ Insulin $\mu \mathrm{IU} / \mathrm{ml}$} \\
\hline $1-7 \mathrm{~d}$ & $8.7^{c}$ & $13.1^{\mathrm{a}}$ & $10.3^{\mathrm{b}}$ & $11.4^{\mathrm{c}}$ & $10.7^{\mathrm{b}}$ & $8.8^{c}$ & 1.7 \\
\hline $8-21 \mathrm{~d}$ & $10.4^{\mathrm{c}}$ & $17.4^{\mathrm{a}}$ & $15.2^{\mathrm{b}}$ & $13.7^{\mathrm{c}}$ & $12.9^{\mathrm{b}}$ & $10.4^{\mathrm{c}}$ & 2.2 \\
\hline $22-70 \mathrm{~d}$ & $21.2^{\mathrm{c}}$ & $23.2^{\mathrm{ab}}$ & $24.3^{\mathrm{a}}$ & $24.9^{\mathrm{b}}$ & $22.9^{\mathrm{a}}$ & $22.5^{\mathrm{b}}$ & 0.8 \\
\hline \multicolumn{8}{|c|}{ BHBA $\mu \mathrm{M} / \mathrm{L}$} \\
\hline $1-7 \mathrm{~d}$ & $0.65^{\mathrm{b}}$ & $0.62^{\mathrm{b}}$ & $0.64^{\mathrm{b}}$ & $0.65^{\mathrm{b}}$ & $0.75^{\mathrm{a}}$ & $0.72^{\mathrm{a}}$ & 0.04 \\
\hline $8-21 \mathrm{~d}$ & $0.84^{\mathrm{a}}$ & $0.73^{\mathrm{b}}$ & $0.82^{\mathrm{a}}$ & $0.72^{\mathrm{a}}$ & $0.81^{\mathrm{a}}$ & $0.78^{\mathrm{a}}$ & 0.02 \\
\hline $22-70 \mathrm{~d}$ & $0.91^{\mathrm{a}}$ & $0.74^{\mathrm{b}}$ & $0.75^{\mathrm{a}}$ & $0.75^{\mathrm{a}}$ & $0.82^{\mathrm{ab}}$ & $0.88^{\mathrm{ab}}$ & 0.06 \\
\hline \multicolumn{8}{|c|}{ NEFA $\mu \mathrm{M} / \mathrm{L}$} \\
\hline $1-7 \mathrm{~d}$ & $590^{\mathrm{a}}$ & $492^{c}$ & $510^{\mathrm{b}}$ & $523^{\mathrm{b}}$ & $515^{b}$ & $521^{\mathrm{b}}$ & 42 \\
\hline $8-21 \mathrm{~d}$ & $615^{\mathrm{a}}$ & $580^{\mathrm{b}}$ & $515^{\mathrm{b}}$ & $530^{\mathrm{b}}$ & $624^{a}$ & $595^{\mathrm{b}}$ & 38 \\
\hline $22-70 \mathrm{~d}$ & $658^{\mathrm{a}}$ & $525^{b}$ & $531^{b}$ & $569^{b}$ & $635^{\mathrm{a}}$ & $607^{a}$ & 33 \\
\hline
\end{tabular}

abMeans in the same row with different superscripts differ $(\mathrm{P}<0.05)$

$\mathrm{T} 1=\mathrm{LAB} /$ SIUS pre and postpartum

T2=LAB/SIUS postpartum

T3=LAB/SIUS prepartum

\section{T4=No LAB/SIUS}

The excretion of Purine derivatives (PDe) $\left(\mu \mathrm{mol} / \mathrm{W}^{0.75}\right)$ in urine was affected $(\mathrm{P}<0.05)$ by the addition of LAB/SIUS in the diets pre and postpartum (Table 6). Lactobacillum plantarum, L. helveticus, L. delbrueckii, Lactococcus lactis cremoris and Leuconostoc mesenteroides were identified. The mean counts of Lactobacilli were 3.6 and 4.4 million $/ \mathrm{ml}$ at the first day of milking in LAB/SIUS and control respectively, increasing to 15.5 million/ml LAB/SIUS and 6.2 non probiotic diet, in 7 days $(\mathrm{P}<0.05)$.

\section{Discussion}

The effect of probiotic supplementation on milk yield and reproduction has been studied previously in dairy cows [3]. Researchers in Japan reported higher milk production and total amounts of fat, protein and non-fat solids in milk of dairy cows supplemented with a prebiotic/probiotic combination [5], similar to the LAB/SIUS symbiotic effect observed in the present work. On the other hand, previous studies on probiotics have presented controversial results with respect to growing performance and health status of calves. Some researchers [21-24] reported that probiotic use during pre-weaning period did not change the calf's performance. Ruminant health status has generally been affected positively by probiotics [11]. In the present observation, health status was improved especially taking into consideration diarrhea and mastitis, both practically absent. Other work on the use of probiotics in calves resulted in higher growth [25-29] showed that calves fed probiotics had $11 \%$ less health problems than those fed diets without probiotic, decreasing by $37 \%$ the incidence of diarrhea, suggesting improvements in growing could be dependent on rearing conditions. Although modes of action of the probiotics are still under discussion, it is generally accepted to improve health and vitality of animals and reducing mortality [30-33]. The beneficial effects of probiotics on animal health and vitality are usually attributed to their stimulant effects on the specific immunological response to antigens and pathogens.

Yasuda et al. [5] evaluated the effect of a new symbiotic consisting of LAB probiotic and its dextran as a prebiotic. The mixture did improve milk production of Holstein dairy cows. It was suggested that the administration of probiotics, in conjunction with specific prebiotics encourages colonization by probiotics, improves microflora in the intestine and, as a result, higher milk yields and milk components, In the present study joint effect of the LAB 
probiotic with the prebiotic effect of SIUS was able to improve milk production, probably due to an increase in DM intake and glucose availability in the experimental animals.

Our results with respect to health status and mortality are in agreement with the findings of $[23,27,29]$. The results obtained in the present experiment suggest that probiotics based on Lactobacillus $s p$. improved health status of cows with decreasing medication cost. When evaluating blood parameters in terms of metabolic transition (fewer predispositions to metabolic disease) and animal performance for LAB/SIUS treatments, the optimal situation would be to have particular treatment elevation of blood glucose and insulin with a reduction in BHBA and NEFA compared with other treatments or the non-treated control. This scenario suggests a reduction of fatty acid mobilization, more complete oxidation of fatty acids, and increased energy derived from dietary carbohydrate sources (i.e., DMI) to meet postpartum energy needs [7]. Our blood parameter findings pre and post-partum were in agreement with those published by Noecek et al. [7] in terms of ease of transition (less predisposition to metabolic disease) and animal performance in high producing Holstein cows. Probably LAB/SIUS decreased fatty acid mobilization and increased available glucose, which will explain increases in milk production (Table 4).

The supply of amino genic and glucogenic substrates may be less optimal relative to lipogenic or ketogenic substrate, similar to the effect of direct-fed microbial supplementation [7]. Providing LAB/SIUS during pre or post-partum only showed an intermediate response, however milk production impact during lactation was generally greater when LAB/SIUS was given after calving, probably due to the sudden impact of higher glucose availability. The onset of these events is highly dependent on the sustenance of DMI. LAB/ SIUS stimulated DMI pre and post-partum probably due to the increased amount of digestibility of forage cell walls by LAB/SIUS and increased intake due to augmentation of milk production in the treated cows. Drackley [34] indicated the source of metabolic fuels that constitutes metabolizable energy may be critical for fine- tuning events that trigger either clinical or subclinical disease, i.e., the supply of aminogenic and glucogenic substrates may be less optimal relative to lipogenic or ketogenic substrates. The onset of these events is also highly dependent on the sustenance of DMI. In the present study an increase of DMI was demonstrated when LAB/SIUS was utilized pre and post-partum, which suggested that either control cows had depressed intake, or the LAB/SIUS had a stimulatory effect, or both. DMI increase could be the key to higher milk production as demonstrated in this study.

A pH stabilization is generally associated with decreased levels of lactic acid in the rumen. The stimulation of lactic acid-utilizing bacteria induced decreases in lactic acid concentrations and the corresponding moderation of ruminal $\mathrm{pH}$. Average ruminal $\mathrm{pH}$ in the present study (Table 3) differed between the diet treatments, being lower for the LAB/SIUS treatment $(\mathrm{P}<0.05)$. The limited amount of concentrate in diet could explain the decrease of $\mathrm{pH}$ due to high VFA formation, while the effective utilization of VFA by lactic acid bacteria could explain the moderation of acidity by the LAB/SIUS diet. Treatment with LAB probiotic of the diet caused higher concentrations of ruminal ammonia (Table 3 ) in comparison with non-supplemented animals $(\mathrm{P}<0.05)$. Differences in ruminal ammonia $\mathrm{N}$ could be associated with stimulation of proteolytic bacteria [35].

Satter \& Slyter [36] suggested a concentration of 3-5mg of $\mathrm{NH}_{3} / 100 \mathrm{ml}$ of ruminal liquid as optimal to increase ruminal microorganism growth. results of the present study will fill easily the suggested ammonia concentration requirements (14 vs $17 \mathrm{mg} / 100 \mathrm{ml}$ ) in $\mathrm{T} 1$ and $\mathrm{T} 2$, respectively, (Table 3). Increasing $\mathrm{LAB}$ counts have been reported before due to the added effect of a favorable prebiotic formula that allows bacteria growth, providing energy and amino acids for microorganism reproduction [11]. Utilization of a mixture of LAB/SIUS probably permitted the proliferation of ruminal bacteria as demonstrated in the present data and confirmed by purine formation (Table 6).

Table 6: Urinary excretion of purine derivatives ( $\mathrm{mmol} / \mathrm{WO} .75$ ) in cows fed with or without LAB/SIUS probiotics.

\begin{tabular}{|c|c|c|c|c|}
\hline & Allantoin & Uric Acid & Total PDe & $\begin{array}{c}\text { Microbial } \\
\text { nitrogen g/d }\end{array}$ \\
\hline Non-LAB/SIUS Pre partum & $417.5 \pm 7.1^{\mathrm{b}}$ & $73.7 \pm 3.3^{\mathrm{a}}$ & $491.2 \pm 9.2^{\mathrm{b}}$ & $33.9 \pm 1.1^{\mathrm{c}}$ \\
\hline LAB/SIUS Pre partum & $492.1 \pm 9.7^{\mathrm{a}}$ & $86.4 \pm 2.4^{\mathrm{a}}$ & $578.5 \pm 8.6^{\mathrm{a}}$ & $42.1 \pm 0.9^{\mathrm{a}}$ \\
\hline T1 & $492.2 \pm 8.4^{\mathrm{b}}$ & $85.7 \pm 3.3^{\mathrm{a}}$ & $577.9 \pm 5.2^{\mathrm{a}}$ & $42.6 \pm 2.3^{\mathrm{a}}$ \\
\hline T2 & $472.4 \pm 6.5^{\mathrm{a}}$ & $80.0 \pm 1.4^{\mathrm{a}}$ & $552.4 \pm 8.6^{\mathrm{a}}$ & $40.2 \pm 1.4^{\mathrm{a}}$ \\
\hline T3 & $437.3 \pm 5.4^{\mathrm{b}}$ & $72.0 \pm 3.3^{\mathrm{a}}$ & $509.3 \pm 6.2^{\mathrm{b}}$ & $35.1 \pm 0.5^{\mathrm{b}}$ \\
\hline T4 & $406.1 \pm 6.3^{\mathrm{a}}$ & $71.8 \pm 1.4^{\mathrm{a}}$ & $479.9 \pm 7.6^{\mathrm{b}}$ & $32.9 \pm 0.8^{\mathrm{c}}$ \\
\hline
\end{tabular}

abMeans in same column with different superscript differ $(\mathrm{P}<0.05)$ between treatments

$\mathrm{T} 1=\mathrm{LAB} / \mathrm{SIUS}$ pre and postpartum

T2 $=$ LAB/SIUS postpartum

T3=LAB/SIUS prepartum

$\mathrm{T} 4=$ No LAB/SIUS 


\section{Conclusion}

Feeding LAB/SIUS containing a probiotic and a prebiotic mixture, beginning $21 \mathrm{~d}$ pre partum and throughout $\mathrm{d} 70$ of lactation increased DMI, milk production, and milk protein percentage throughout the first $21 \mathrm{~d}$ of lactation. The pre partum and post-partum probiotic diets did improve quantity and quality of milk production. There were enhanced metabolic profiles in cows, as reflected by glucose, insulin, NEFA and BHBA status. The performance of cows supplemented with LAB/SIUS pre and/ or post-partum beginning of parturition throughout $\mathrm{d} 70$ was higher milk production and augmentation of DMI. Addition of a LAB probiotic accompanied by a prebiotic mixture augmented $\mathrm{N}$ intake by $23 \%$, increased microbial protein synthesis and improved rumen physiology by increasing fibre degradation.

\section{References}

1. Park YW (2009) Bioactive components in milk and dairy products. Weley-Blackwell Publ, USA, p. 426.

2. Couret V, Gueguen M, Vernoux JP (2004) Number and strains of lactobacilli in some probiotic products. International Journal of Microbiology 97(2): 147-156.

3. Maulden GL (2008) Effect of dietary modulation of intestinal microbiota on reproduction and early growth. Theriogenology 70(3): 286-290.

4. Gibson GR, Roberford MR (1995) Dietary modulation of the human colonic microbial: Introducing the concept of prebiotics. J Nutrition 125(6): 1401-1412

5. Yasuda K, Hashikawa S, Sakamoto H, Tomita Y, Shibata S, et al. (2007) A new symbiotic consisting of Lactobacillus casei subsp. casei and dextran improves milk production in Holstein dairy cow. J Vet Med Sci 69(2): 205-208.

6. Jouany JP (2006) Optimizing rumen functions in the close-up transition period and early lactation to drive dry matter intake and energy balance in cows. Animal Reproduction Science 96(3-4): 250-264.

7. Nocek JE, Kautz J, Leedle Z, Block E (2003) Direct-fed microbial supplementation on the performance of dairy cattle during the transition period. J Dairy Sci 86(1): 331-335.

8. Holzapfel WH (2002) Appropiate starter culture technologies for smallscale fermentation in developing countries. Int J Food Microbiol 75(3): 197-212.

9. Konings WN, Kok J, Kuipers OP, Poolman B (2000) Lactic acid bacteria: the bug of the new millennium. Curr Opin Microbiol 3(3): 276-282.

10. Adams MR (1999) Safety of industrial lactic acid bacteria. J Biotechnol 68(2-3): 171-178.

11. Galina MA, Rubio MAO, Pertiñez MD, Pineda LJ (2009) Goat kid's growth improvement with a lactic probiotic fed on a standard base diet Nutritional and Foraging Ecology of Sheep and Goats 85: 315-322.

12. Rubio MAO, Ørskov ER, Milne J, Galina MA (2007) Effect of different sources of nitrogen on in situ degradability and feed intake of Zebu cattle fed sugarcane tops (Saccharum officinarum). Feed Science and Technology 139: 143-158.

13. Dawson KA, Newman KE, Boling JA (1990) Effects of microbial supplements containing yeast and lactobacilli on roughage fed ruminal microbial activities. J Anim Sci 68(10): 3392-3398.

14. Galina MA, Guerrerro M, Puga DC (2007) Fattening pelibuey lambs with sugar cane tops and corn complemented with or without slow intake urea supplement. Small Rum Res 70(2-3): 101-109.

15. Hungate PE (1969) A roll tube method for cultivation of strict anaerobes. In: Norris JR, Ribbons DW (Eds.), Microbiology. Academic Press, London, UK, pp. 117-132.

16. AOAC (1998) Official methods of analysis. In: $\left(16^{\text {th }}\right.$ edn), Association of Official Agricultural Chemesist $4^{\text {th }}$ Revision. Washington, USA.

17. Soest PJ, France J, Siddons RC (1992) On the steady-state turnover of compartments in the ruminant gastrointestinal tract. Journal of Theoretical Biology 159(2): 135-145.

18. Chen XB, Gomes MJ (1992) Estimation of microbial protein supply to sheep and cattle based on urinary excretion of purine derivatives an overview of the technical details. IFRU-Rowett Research Institute. Occasional publication, p. 21.

19. Chen XB, Ørskov ER (2004) Research on urinary excretion of purine derivatives in ruminants: Past, present and future. In: Makkar PS, Chen $\mathrm{XB}$ (Eds.), Estimation of microbial protein supply in ruminants using urinary purine derivatives. FAO/IAEA, pp. 180-210.

20. Gibbard S, Watkins PJ (1968) A micro-method for the enxymatic determination of D-beta-hydroxybutyrate and acetoacetate. Clin Chim Acta 19(3): 511-521.

21. Skrivanova V, Machanova L (1990) Influence of Lactobacillus acidophilus probiotics on efficiency and parameters of rumen fluid in calves. Zivocisna Vyroba 35(1): 87-94.

22. Avila FA, Paulillo AC, Iturino RPS, Lucas FA, Orgaz A, et al. (1995) A comparative study of the efficiency of a probiotic and the anti-K99 and anti-A14 vaccines in the control of diarrhea in calves in Brazil. Revue d'elevage de Medecine Veterinaire des Pays Tropicaux 48(3): 239-243.

23. Tarboush HM, Saiady MY, Keir AHD (1996) Evaluation of diet containing lactobacilli on performance, fecal coliform, and lactobacilli of young dairy calves. Anim Feed Sci Techn 57(1-2): 39-49.

24. Morrill JL, Morrill JM, Feyerherm AM, Laster JF (1995) Plasma proteins and a probiotic as ingredients in milk replacer. J Dairy Sci 78(4): 902907.

25. Cerna B, Cerny M, Betkova H, Patrichny P, Soch M, et al. (1991) Effect of the proma probiotics on calves. Zivocisna Yyroba 36: 381-388.

26. Feist K, Nagel S, Voigt J (1997) Microbial cultures versus germs causing diarrhea. Probiotic against calf diarrhea. Neu Landwirtschaft 2: 66-68.

27. Abe FI, Shimamura SN (1995) Effect of administration of bifidobacteria and lactic acid bacteria to newborn calves and piglets. J Dairy Sci 78(12): 2838-2846.

28. Strzetelski J, Maciejewicz RJ, Bilik K, Stasiniewicz T, Lipiarska E, et al. (1996) Effect of new yeast preparations on calf rearing, rumen fermentation and protozoa population in the rumen of young bulls. Roczniki Naukowe Zootechniki 23: 123-141.

29. Gill DR, Smith RA, Ball RL (1987) The effect of probiotics feeding on health and performance of newly arrived stocker calves. Anim Sci Res Report, pp. 202-204.

30. Vanbelle M, Teller E, Focant M (1990) Probiotics in animal nutrition: a review. Berlin Arch Tierenaehr 40(7): 543-567.

31. Siuta A (1997) The role of probiotics in the organism. Acta Agraria et Silvestria. Series Zoo Technica 35: 33-45.

32. Fuller R (1992) Probiotics-scientific basic. Chapman and Hall. London, UK.

33. Fuller R (1996) Probiotics for farm animals. In: Roth FX, Kirshgessner M, Eidelsburger B (Eds.), IDF Nutrition 5: 29-30. 
34. Drackley JH (1999) Biology of dairy cows during the transition period: the final frontier? J Dairy Sci 82(11): 2259-2273.

35. Newbold CJ, Wallace RJ, Chen XB, McIntosh FM (1995) Different strains of Saccharomyces cerevisae differ in their effects on ruminal bacterial numbers in vitro and in sheep. J Anim Sci 73(6): 1811-1818.

36. Satter LD, Slyter LL (1974) Effect of ammonia concentration of rumen microbial protein production in vitro. Br J Nutr 32(2): 199-208.

For possible submissions Click below: 